\title{
Does it Pay to Venture Abroad? Exporting Behavior and the Performance of Firms in Indian Industry
}

\author{
Pradeep K. Chhibber ${ }^{\mathrm{a}}$ and Sumit K. Majumdar ${ }^{\mathrm{b}, *}$ \\ ${ }^{a}$ Department of Political Science, University of Michigan, Ann Arbor, MI 48109, USA \\ ${ }^{\mathrm{b}}$ University of Michigan Business School, Ann Arbor, MI 48109, USA
}

\begin{abstract}
Using contemporary data for a firm-level sample of over 600 Indian firms, this paper investigates the impact that an export-orientation has on the profitability of the firms studied. The results, based on a two-stage least squares method, establish a positive and significant relationship between firms' levels of exports and profitability. For firms from developing and transition economies like India it does pay to venture abroad, and the ability to sell goods overseas has a significant impact on firms' economic performance. (C) 1998 John Wiley \& Sons, Ltd.
\end{abstract}

\section{INTRODUCTION}

For a number of developing and transitioneconomies a major thrust of their current reforms process is the encouragement of exports, following examples of the export-led growth stories of the Asian tigers such as Singapore, South Korea, Taiwan and lately China. Encouragements to export have been provided to the firms that operate in these developing or transition economies. Yet, there is relatively little contemporary evidence which shows whether export-oriented developing or transition-economy firms are relatively superior in performance in comparison with those firms that are relatively less export-oriented.

This paper reports the results of an empirical study examining the impact of an export orientation on the profitability of firms, for an extensive sample of Indian firms. India is a rather unique case because its industrial policy of the 1960s and the 1970s was autarkic in nature, import-substituting in character and based on an extreme export-pessimism (Mohan and Aggarwal, 1990). Since the 1980s, and particularly since the onset of the liberalization process in 1991, there has been a

* Correspondence to: University of Michigan Business School, 701 Tappan Street, Ann Arbor, MI 48109-1234, USA. realization that a high rate of growth in exports, to improve India's dismally-low share of world trade, is essential for spurring economic development.

A number of Indian firms have accepted the challenge of expanding their presence in overseas markets, and this study investigates whether the process of venturing abroad has had an impact on firms' performance, which, following standard practice in the industrial organization literature (Cowling and Waterson, 1976), is measured as profitability. Therefore, the results that are generated have important firm-level as well as public policy implications as to whether being an exportoriented firm is economically beneficial. The paper unfolds as follows. In the next section theoretical issues are discussed. The section after describes the empirical research procedures, while the following section contains a discussion of the results and the last section contains a brief conclusion.

\section{THEORY}

There is no specific theory, per se, which links the export-orientation of firms to their performance; however, extant theories of trade and foreign

CCC 0143-6570/98/020121-06\$17.50

(C) 1998 John Wiley \& Sons, Ltd. 
direct investment do provide a useful starting point. Traditional trade theories have used country-specific factors to explain trade patterns, at a relatively aggregated level of analysis, while recent theories of foreign direct investment have focused on firm-related and industry-related factors as to why firms venture abroad. Among the firm-specific factors are access to factor markets, established international market linkages and the possession of a range of technological and organizational capabilities. These factors prognosticate on the ability of firms to venture abroad to sell their goods, either via the exports of products manufactured in the home country, or via direct investment in manufacturing and commercial operations in a host country (Caves, 1982).

A relatively fruitful and well-used explanation of why firms venture abroad lies in the possession of idiosyncratic, and perhaps superior, technological and organizational capabilities that firms possess, and which are reflected in the ownership of intangible assets and resources. Such intangible assets may represent codified and tacit knowledge about production processes which helps drive costs down and enables the servicing of overseas markets cheaply, or may take the form of a patented process, or may take the form of design and research know-hows that are shared among a critical mass of firms' employees. Another intangible asset can be marketing skills, which are reflected in a brand image or style that generates demand from overseas customers.

The above explanations are useful in understanding the question of why firms might venture abroad. Rather little theory, however, exists in the literature to explain whether firms that do venture abroad show superior performance as a whole, as a consequence of doing so, relative to their homecountry counterparts which have been less geographically-adventurous. The theory of foreign direct investment provides a starting point. $A$ priori, it can be argued that firms which possess superior capabilities, which are reflected in the possession of intangible assets, are also likely to perform better than their domestic counterparts. Specifically with regard to the degree of multinationality, returns to intangible assets (Dunning, 1973), market power conferred by international scope (Hamel and Prahalad, 1985) and the capacity to undertake riskier activities with commensurately-superior returns (Agmon and Lessard, 1977) are factors which have been found to lead overseas-oriented firms to perform better.

(C) 1998 John Wiley \& Sons, Ltd.
With respect to firms which are principally exporters, if domestic and overseas markets are both equally competitive, or both closed for that matter, differences in competitive intensity between these two markets are going to be small; performance differences, however, between export-oriented and domestically-oriented firms are unlikely to be minimal. The superior firms which have ventured abroad as exporters are likely to perform better than the other not-so-good firms which have stayed at home, because for the overseasventuring firm it is the possession of superior capabilities which not only induces it to venture abroad but also results in superior performance at home. However, equally-good firms which have stayed at home are not likely to materially differ in performance from those firms which have gone abroad.

Conversely, often domestic markets are controlled, as has been the case in many developing and transition economies, such as India which is only now in the process of opening up her markets to full competition (Jalan, 1991). In such cases, where domestic markets are closed compared with the export markets in which firms from these countries operate in, then significantly superior performance will be noted for firms that have a relatively greater export orientation.

The above hypothesis is based on the assumption that firms from a relatively closed domesticeconomy environment are likely to face a more intensive competitive environment abroad with respect to their export operations. Not only are there domestic target-country firms operating in the overseas markets, but it is very likely that there are a number of firms from other thirdcountries trying to acquire market shares as well in the overseas markets. As a result, export-oriented firms from closed-economy countries will have to be efficient if they are to be able to sell their products or services at competitive prices. Simultaneously, the items in question that are being sold have to be of a high-enough quality, given the wide range of choices that are likely to be available to overseas customers. These pressures necessitate the acquisition of superior skills and capabilities by the export-oriented firm as a whole, so as to be able to succeed in overseas markets in competition with other players in these markets.

The acquisition of skills which enhance efficiency so as to be competitive in overseas markets

Manage. Decis. Econ. 19: 121-126 (1998) 
generates capabilities across the firm as a whole. The acquisition of these skills and capabilities has a spillover effect into the total operations of an export-oriented firm, and enable it to be a superior performer when its performance is compared with the performance of a less export-oriented firm. Other than the acquisition of tangible skills and capabilities which enable an export-oriented firm to survive abroad, the very experience of operating overseas leads to the acquisition of a wider range of experiences which are not available to a less export-oriented firm. This learning leads to the enhancing of organizational variety within an export-oriented firm, which again can be leveraged towards improving the performance of an export-oriented firm's operations as a whole.

\section{EMPIRICAL ANALYSIS}

The sample on which the empirical analysis is carried out consists of 645 firms which are listed on the Bombay Stock Exchange. Initially, a larger random sample was extracted from the data base, but missing variable problems finally brought the sample down. This is a very large sample compared with previous studies of Indian industry which have been based on aggregate statistics, and firm-level analyses of Indian industrial issues are relatively rare. While firm-level analyses exist, the data used in those studies are over 10 years old and the generalizations drawn from such studies have no meaning in the changed Indian economic context.

The source of the data was the Center for Monitoring the Indian Economy in Bombay, India. The data collected for each firm relates to a specific year between 1988 and 1994, with the reason for data collection ranging over a number of years being the availability of information with respect to several key variables. The dependentvariable for performance, profitability, is measured as return on net worth, and the key independent variable is the $\log$ of exports, $E X$ PORTS, which captures the export intensity of the firms studied. These are standard variables in the literature (Grant, 1987; Helleiner, 1992).

A problem in estimating a profit function where the level of exports is treated as an independent variable is endogeneity. In econometric terms, a regression model containing EXPORTS as an independent variable may lead to inconsistent OLS

(C) 1998 John Wiley \& Sons, Ltd. estimates because EXPORTS will be contemporaneously correlated with the error term. A method of dealing with such situations is the instrumental variables approach which is equivalent to a twostage least squares estimation (Gujarati, 1988). A popular instrumental variable is the lagged value of the independent variable in question. We cannot construct this variable because we have crosssectional data. We instead estimate EXPORTS as a function of a number of instrumental variables that in the literature are correlated with firms' export orientation. The instruments are $I M$ PORTS, CAPITAL INTENSITY and FOREIGN, and a set of dummies for the following industries, CHEMICAL, MACHINERY, FOOD, MINING, FINANCE, AGRICULTURE and TEXTILES, for the firms represented in our data set. Each of these variables can influence the export orientation of firms.

A higher level of imports enables higher quality finished goods to be produced for global markets and higher prices to be realized as firms can differentiate their products. Such higher price realizations can positively impact firms' profitability, and firms can import goods so as to be able to supply the export market and make higher profits. The import of inputs is shown to facilitate capability-building through providing embodied knowledge which takes purchasing-country firms to a higher quality trajectory, which in turn improves the competitiveness of exports (Krueger, 1983; Grossman and Helpman, 1991).

A variable for capital intensity controls for variations in firms' input structures. Differences in input structure between firms can be associated with factors such as managerial decisions as to what is the optimal feasible level for a particular input. In the literature, however, a key assumption is that firms will export items for which the country that they are based in has relatively abundant factor endowments (Magee, 1980). For India, that factor is cheap labor. Therefore, labor intensive firms are likely to export more because of a relative cost advantage and, in the context of a labor-rich country such as India, exports are more likely to embody human capital inputs rather than physical capital inputs.

Foreign firms are also likely to be greater exporters. The reasoning is that firms in which there is higher foreign ownership possess capabilities, such as global marketing skills, which other firms may not. Foreign firms also have superior capa-

Manage. Decis. Econ. 19: 121-126 (1998) 
bilities which lead them to become international players in the first place (Caves, 1982). They possess international marketing capabilities, a global operations network, in-depth knowledge of foreign markets and the ability to manage political economy issues so as to overcome trade barriers. Also, the relatively cheaper cost of production in developing countries can be exploited for global supply purposes. Additionally, firms which have operated fully-owned subsidiaries in India have had an obligation to the government that they will be intensive exporters.

The profit function that is subsequently estimated then includes EXPORTS as the primary variable of interest, while GROUP, SIZE, AGE, DIVERSITY, ADVERTISING, MARKETING, DISTRIBUTION, INVENTORY, LIQUIDITY and $D E B T$ are included as regressors to control for other factors that affect firms' performance (Caves and Barton, 1990).

Within India a number of business groupings exist, because the origins of Indian enterprise have been based on trading families who subsequently financed forays into industry. Belonging to a group is expected to lead to capability-spillovers among the firms comprising the group, with a positive impact on the performance of individual firms, as a result of the existence of scope economies in operational areas.

Size is an important control. Our data is crosssectionally extensive, but we do not have the ability to measure firm's market-power or the level of concentration in the industries that the firms in our sample operate in. This is a major limitation of the data, and we cannot include controls for market-structure factors which are important drivers of economic performance. Size reflects the ability of firms to attain economies of scale as well as market power. The industrial organization literature suggests that older firms are more experienced and can enjoy superior performance compared with newcomers. On the other hand older firms are prone to inertia, and unlikely to be flexible enough to make rapid adjustments. Therefore, performance may suffer.

The quantum of diversification of business activities by a firm also affects performance. Related diversification is one way of exploiting a firms' excess capacities, and may lead to better performance for the firm as a whole. Unrelated diversification, on the other hand, away from the core activities of the firm, can lead to lower than

(C) 1998 John Wiley \& Sons, Ltd. average performance because it leads to a dissipation of energies and resources into areas which demand more than necessary attention. Thus, the relative diversification of business activities by firms impacts on firms' performance.

Advertising and firm-level performance can be positively related, with advertising leading to product differentiation, while marketing expenditures lead to more information about firms' products being available. Distribution expenditures widen the physical range of coverage and the variable proxies for geographic market heterogeneity. Environmental factors have a strong impact on performance. The level of inventories captures aspects of firm-level competencies since some firms within a given industry may turn out to be better managers of working capital than others; also some industries can have higher inventory holding patterns relative to others. Similarly, in some industries growth in sales may be higher or lower compared with others leading to inventory build-ups.

Finally, government policies can affect performance. In India the state has stepped in as a provider of long-term capital for industrial projects because equity markets were underdeveloped. Principal-agent reasoning suggests that the greater the level of debt, the greater the amount of lender monitoring; therefore, firms' performance will be better. In India, such principalagent concepts have been reversed, because in spite of the presence of a large debt the lack of monitoring by government-owned lenders has permitted industrialists to earn large rents on low personal investments and there have been very muted incentives for firms to attain superior performance.

\section{RESULTS}

The two-stage least squares results with robust standard errors are presented in Table 1. The model is significant, with the $R^{2}$ being 0.247. As shown, the coefficient for EXPORTS is positive and significant. The analysis reveals that for Indian firms the level of sales made abroad does enhance the profitability of firms. A body of evidence for British, US and other-country firms (Kumar, 1984; Grant, 1987) does exist which finds that firms which operate multinationally, primarily as foreign direct investors, do out-perform

Manage. Decis. Econ. 19: 121-126 (1998) 
domestically-oriented firms. Similar evidence for Indian firms does not exist because Indian industry has as yet not had a history of its firms undertaking large-scale foreign direct investment. Nevertheless, Indian firms which are outward oriented perform better; this evidence is in consonance with evidence from other countries.

These results are obtained after controlling a number of other factors, and lend support for the hypothesis that developing or transitioneconomy firms, used to operating in relatively closed domestic markets, show superior performance if they venture abroad where they might tend to face more intense competitive pressures. Additionally, where exports is an independent variable a problem is endogeneity. Our two-stage model also treats exports as an endogenous variable. Hence, our finding that the relationship of exports to profitability is positive and significant is robust.

\section{CONCLUSION}

The idea that free trade leads to superior economic performance, construed in a broad sense, dates back at least to Adam Smith. In the literatures on either economic development, international trade, industrial organization or management a common result that is accepted as

Table 1. Two-stage Regression Results

\begin{tabular}{lclr} 
Variable & $\begin{array}{l}\text { Coefficient } \\
\text { estimate }\end{array}$ & $\begin{array}{l}\text { Standard } \\
\text { error }\end{array}$ & $t$ ratio \\
\hline EXPORTS & 1.875 & 0.926 & 2.02 \\
GROUP & -1.227 & 1.005 & 1.22 \\
SIZE & -1.369 & 0.859 & 1.59 \\
AGE & -0.048 & 0.022 & 2.12 \\
DIVERSITY & 0.304 & 0.862 & 0.35 \\
ADVERTISING & -0.736 & 0.325 & 2.26 \\
MARKETING & 0.092 & 0.181 & 0.51 \\
DISTRIBUTION & -0.396 & 0.184 & 2.14 \\
INVENTORY & -0.282 & 0.040 & 6.93 \\
LIQUIDITY & 14.980 & 1.938 & 7.73 \\
DEBT EQUITY & -0.489 & 0.183 & 2.67 \\
CONSTANT & 30.536 & 2.765 & 11.04 \\
$R^{2}$ & 0.247 & & \\
$F$ & 18.64 & & \\
$N$ & 645 & & \\
\hline
\end{tabular}

(C) 1998 John Wiley \& Sons, Ltd. standard is that greater levels of exposure to international trade leads to superior firm-level economic performance (Bhagwati and Srinivasan, 1979; Nishimizu and Robinson, 1984; De Melo and Urata, 1986; Porter, 1990; Helleiner, 1992). In this paper the question of whether firms that have a relatively greater export orientation than others also perform better was examined, for a large sample of Indian firms using very contemporary data. The results have immediate policy implications, and the patterns of findings show that, indeed, firms which have greater exports do also have a higher rate of profitability. Therefore, from a policy point-of-view encouragement of exports that are being made by many developing and transition economies are likely to yield pay-offs in terms of superior economic performance.

\section{REFERENCES}

T. Agmon and D. Lessard (1977). Investor recognition of corporate international diversification. Journal of Finance, 32, September, 1049-55.

J.N. Bhagwati and T.N. Srinivasan (1979). Trade policy and development. In International Economic Policy: Theory and Evidence (edited by R. Dornbusch and J.A. Frenkel), Baltimore, MD: Johns Hopkins University Press.

R.E. Caves (1982). Multinational Enterprise and Economic Analysis, Cambridge, MA: The MIT Press.

R.E. Caves and D. Barton (1990). Efficiency in U.S. Manufacturing Industries, Cambridge, MA: The MIT Press.

K. Cowling and M. Waterson (1976). Price-cost margins and market structure. Economica, 43, 267-74.

J. De Melo and S. Urata (1986). The influence of increased foreign competition on industrial concentration and profitability. International Journal of Industrial Organization, 4, 287-304.

J.H. Dunning (1973). The determinants of international production. Oxford Economic Papers, 25, November, 289-336.

R.M. Grant (1987). Multinationality and performance among British manufacturing companies. Journal of International Business Studies, 17, Fall, 79-89.

G. Grossman and E. Helpman (1991). Innovation and Growth in the Global Economy, Cambridge, MA: The MIT Press.

D. Gujarati (1988). Basic Econometrics, 2nd edition, New York: McGraw Hill.

G. Hamel and C.K. Prahalad (1985). Do you really have a global strategy?, Harvard Business Review, 63, July-August, 139-48.

G.K. Helleiner (1992). Introduction. In Trade Policy, Industrialization and Development (edited by G.K. Helleiner), Oxford: Oxford University Press.

Manage. Decis. Econ. 19: 121-126 (1998) 
B. Jalan (1991). India's Economic Crisis: The Way Ahead, New Delhi: Oxford University Press.

A.O. Krueger (1983). Trade and Employment in Developing Countries, Chicago: University of Chicago Press.

M.S. Kumar (1984). Growth, Acquisition and Investment, Cambridge: Cambridge University Press.

S.P. Magee (1980). International Trade, Reading, MA: Addison-Wesley Publishing Company.
R. Mohan and V. Aggarwal (1990). Commands and controls: planning for Indian industrial development; 1951-1990. Journal of Comparative Economics, 14, $681-712$.

M. Nishimizu and S. Robinson (1984). Trade policies and productivity change in semi-industrialized countries. Journal of Development Economics, 16, 177-206.

M.E. Porter (1990). The Competitive Advantage of $\mathrm{Na}$ tions, New York: The Free Press. 